\title{
Skills and Competencies in Higher Education and Beyond
}

\author{
Lilia Raitskaya \\ Moscow State Institute of International Relations (MGIMO University) \\ Correspondence concerning this article should be addressed to Lilia Raitskaya, MGIMO University, $76 \mathrm{Pr}$. \\ Vernadskogo, Moscow, Russia, 119454.E-mail: raitskaya.l.k@inno.mgimo.ru
}

\section{Elena Tikhonova}

National Research University Higher School of Economics; Peoples' Friendship University of Russia (RUDN University)

\author{
Correspondence concerning this article should be addressed to Elena Tikhonova, National Research University \\ Higher School of Economics, 26 Shabolovka, Moscow, Russian Federation, 119049. \\ E-mail: etikhonova@hse.ru
}

\begin{abstract}
The editorial focuses on the employability skills and the ways they are reflected in the research field of higher education. The topics related to competencies, abilities, attributes and skills are crucially important as they substantially determine the chances of successful employability for university graduates. The multiple approaches and frameworks covering various kinds of qualifications have been emerging since the 1980s, starting from the 21st century skills to the recent key skills required within education for sustainable development. The UN, European Union, OECD, and other international institutions regularly put forward comprehensive frameworks to address the pressing needs of the transforming economy and society for professionals and specialists ready to face the new challenges. The editorial gives a glimpse of the trends JLE is willingly ready to bring out for our readers in the coming years.
\end{abstract}

Keywords: higher education; skill; competency; $21^{\text {st }}$ century skills; education for sustainability; soft skills; employability skills; labour market; employers' requirements

The modern labour market is being transformed by the changes undergone by the information society and digital economy. Employability requirements have changed to address the new realities and challenges. Information has become a production factor, comprehensively influencing the world. The life cycle of knowledge is considerably shortened. The knowledge acquired within a course of studies at a higher education institution is obsolete by the time graduates get their diplomas.

Automation is widely believed to globally find its way to the workplace by the 2020s. Some of the hard skills and professional competencies are getting insufficient. A host of brand-new and well-revised skills prompted by advances in technology are beginning to loom (see Table 1). In some areas, mismatches of skills as discrepancies between employees' skills and labour market needs have showed up.

It is obvious that by now a new type of workplace has arrived, i.e. a digital workplace. Today, it is of importance what and how the work is done, but it is optional where and when it is done. 'Global competition, the Internet, and the widespread use of technology suggest that the economy of the 21st century will create new challenges for the workforce' (van Laar et al., 2019).

\section{1st Century Skills}

Smart technologies and sophisticated knowledge urge people of the 21st century to develop previously unimportant or emerging skills. The latter as national, regional, and global programmes first came into being in the 20th century to evolve into the 21st century. The first most elaborated and influential framework appeared in the 1980s in the USA as the 21st Century Skills that cover skills themselves, abilities, and learning dispositions.

The US economy faced dramatic structural changes and new shifts that impede economic growth and economic 
development. The political response resulted in a special commission, i.e. the National Commission on Excellence in Education, set up to work out a better understanding of the structural change in the economy and its implications for labour. A comprehensive framework of education for the future became the most essential outcome.

The report titled 'A Nation at Risk' ${ }^{1}$ was published to overhaul the US System of Education as a lot of flaws in the system needed rectifying. The statistics proved the dilapidating state of education: about $23 \mathrm{~m}$ Americans over 18 years old had insufficient reading and writing skills².

The vital findings of the landmark report addressed the basics of the primary, secondary and post-secondary education (the most essential subjects covering English, Mathematics, Science, Social Studies, Computer Science), other important parts of the curriculum (Foreign Languages, Arts and Humanities, etc.), Skills \& Abilities (communicative and interpersonal skills, cognitive skills, digital skills, etc.), and Learning and Educational Technologies. The new understanding of the future of education brought reforms and change. Skills have become the cornerstone in the new system.

\section{Skills in the OECD}

The Organisation for Economic Cooperation and Development has been at the leading edge in studying skills and education at large. It participates in promoting national skills strategies, makes reports and analyses, follows world indicators of skills for employment, sets up frameworks and supports research. Annually, the OECD publishes from 300 to 500 books in addition to reports, statistics, and working papers.

The organisation regularly turns to the skills analyses ${ }^{3}$. In the OECD 'Skills for a Digital World' (2016), there are various groups of skills that are needed, including technical and professional skills, ICT generic skills, soft skills such as leadership, communication and teamwork skills ${ }^{4}$. New skills are a must in the increasingly digital world. 'Government must help ensure that an increasingly digital world yields better quality jobs and that both employers and workers have the means to take advantage of the new job opportunities that open up's. The document enumerates priority changes in skill policies to promote growth: (1) to ensure that basic ICT skills are acquired in within the initial education; (2) education must better anticipate skill needs and guide students towards better learning outcomes; (3) skills needed for the digital economy should be used by employers as well as employees; (4) employers and employees ought to be ready and motivated to get re-skilled and up-skilled any time as skill demands tend to change.

\section{EU Initiatives Relating to Skills and Competencies}

In 1991, the European Language Portfolio was designed to support the Common European Framework of Reference for Languages (CEFR) within the Language Learning for European Citizenship project. The latter aimed to mediate learning, teaching and assessing European languages to all learners and teachers. At the same time, the uniform EU system of validation of language aptitude was set up.

The European Language Portfolio offers its own framework of levels of aptitude (A1-A2-B1-B2-C1-C2) and cultureand language-related skills, including at the moment 544 skills that are still not exhaustive. Language learning implies four basic capabilities (also called skills), i.e. listening, speaking, reading, and writing. The foundation of any language aptitude is described as communication skills, consisting of sub-competencies of grammatical skills, sociolinguistic skills, discourse skills, and strategic skills. The practical outcome of the European Language Portfolio covers all kind of certificates for learners of languages issued within the EU with the stated levels of language aptitude.

\footnotetext{
A Nation at Risk: The Imperative For Educational Reform. An Open Letter to the American People. A Report to the Nation and the Secretary of Education. (1983). Institute of Education Sciences (ERIC). Retrieved from https://eric.ed.gov/?id=ED226006

2 The Excellence Movement in Education and Lessons from History. (1985). Institute of Education Sciences (ERIC). Retrieved from https://eric. ed.gov/?id=ED289236.

3 OECD (2016). Skills for a Digital World: 2016 Ministerial Meeting on the Digital Economy Background Report, OECD Digital Economy Papers, No. 250, OECD Publishing, Paris, http://dx.doi.org/10.1787/5jlwz83z3wnw-en.

OECD (2016). Getting Skills Right: Anticipating and Responding to Changing Skill Needs, OECD Publishing, Paris, http://dx.doi. org/10.1787/9789264252073-en

OECD (2015). OECD Skills Outlook 2015: Youth, Skills and Employability, OECD Publishing, Paris, http://dx.doi.org/10.1787/9789264234178-en. 4 Ibid.

5 OECD (2016). Skills for a Digital World: 2016 Ministerial Meeting on the Digital Economy Background Report, OECD Digital Economy Papers, No. 250, OECD Publishing, Paris, http://dx.doi.org/10.1787/5jlwz83z3wnw-en.
} 
The European Union adopted several directives to launch new educational technologies which encourage new teaching and learning techniques in developing soft skills. To unify all competencies and skills across all EU countries, a new document, called 'Europass of Skills' was introduced in 2004 by the European Parliament and the Council. It is issued in 26 languages of the EU and enables EU citizens to freely migrate within the Single European Market. All skills and competencies are defined and listed as an EU general framework. The EU labour market, thus, had got more 'single' in the sense of uniform employers' requirements (qualifications and skills) towards new hires. The Europass documents skills to find a job or training in the EU countries or validate skills.

Another important document turned up in 2006. It was 'The key Competences for Lifelong Learning - A European Framework' (an annex to a Recommendation of the European Parliament and the Council) 6 . The Reference Framework sets out eight key competences: 1) communication in the mother tongue; 2) communication in foreign languages; 3) mathematical competence and basic competences in science and technology; 4) digital competence; 5) learning to learn; 6) social and civic competences; 7) sense of initiative and entrepreneurship; 8) cultural awareness and expression?

\section{Key Competencies under the Education for Sustainable Development Concept}

The concept of sustainable development came to the fore in the late 1980-s within the United Nations (UN). It emerged as a response to climate change, disaster risks, environmental degradation, resources depletion, destruction of habitats. Previously, the mankind had already made attempts at non-systematical measures and policies to improve the environmental interaction and protection. At all stages, it was education that became the hub of all social change in the approaches and attitudes towards the nature. 'Sustainability's increased prominence in higher education is demonstrated by the growing number of academic programs ...' (Wick, Withycombe \& Redman, 2011).

Wals (2012) put forward a historic timeline, describing the relationship between people and the planet reflected in education. The periods as responses to human interactions with nature correspond to advances in technologies and the industrial revolution at the outset. Starting from 2015, the latest period is, thus, described as 'Environmental and Sustainability Education' (intentional communities, local food movements, shared economies, etc.). It followed the previous 'Sustainability Education' with citizen engagement, participation in sustainable development, and better understanding of the interconnections of the world (Wals, 2012). At present, universities are beginning to serve as the hubs of sustainability awareness.

The education for sustainable development aims to transform the mindset of the society towards sharing the responsibility for the future of the planet. To efficiently achieve the goal, it is vital to turn to transgressive, or transformative learning and develop a host of skills and competencies, enabling people to solve environmentally important problems and lead an environmentally aware way of life. 'Through education, students gain insight into an environmental problem, its consequences and the types of actions required to address it' (Wals \& Benevot, 2017).

'The educational literature on competencies, in general, and competencies in sustainability, in particular, entails a great deal of terminological ambiguity' (Wick, Withycombe \& Redman, 2011). Most researchers overlap in defining key competencies for sustainability as 'critically important for sustainability efforts, distinguishing them from those of other professions and academic programs' (Wick, Withycombe \& Redman, 2011). Based on the comprehensive analysis of the literature, Wick et al. (2011) outlined the following key competencies essential in education for sustainable development: synthesized sustainability research and problem-solving, systems-thinking competence, anticipatory competence, normative competence, strategic competence, and interpersonal competence.

\section{Employability Skills: Hard Skills vs Soft Skills}

Employers' requirements reflect the actual demand for labour in the economy. They cover the essential qualifications, experiences, hard and soft skills, attributes and traits of potential employees. 'Employability subsumes a host of person-centered constructs needed to deal effectively with the career-related changes occurring in today's economy' (Fugate, Kinicki \& Ashforth, 2004), with soft skills coming to the front line.

\footnotetext{
6 The key Competences for Lifelong Learning - A European Framework. Retrieved from http://eur-lex.europa.eu/LexUriServ/site/en/oj/2006/ 1_394/1_39420061230en00100018.pdf

Ibid., p.3.
} 
In the various national and international contexts, the concept of soft skills reflects the social demand in the exact circumstances. The requirements determine the taxonomy used in every context. Whereas hard skills are more or less defined and clear-cut for various occupations, soft skills still exist mainly as 'laundry lists', with much uncertainty and overlapping in definitions and taxonomy.

In our previous research on soft skills, articles, grey literature (reports by governmental institutions and international organisations), and official frameworks were thoroughly considered to find out that there are three major clusters of skills and attributes of soft skills that are included in most classifications. They cover (1) social and communicative skills (communicative skills, interpersonal skills, teamwork and leadership, social intellect, responsibility, ethics of communication); (2) cognitive skills (critical thinking, problem-solving skills, innovative thinking, intellectual load management skills, skills of learning, information skills, time management skills); (3) personal attributes and emotional intellect (emotional intellect, integrity, optimism and positive thinking, flexibility, creativity, motivation, empathy) (Raitskaya \& Tihkonova, 2018). Soft skills are developed in learning and substantially hinged on modes of learning (Nikitina \& Furuoka, 2012).

Suleman in her literature review (2016) concludes that researchers and policy makers ... remain uncertain about graduate skills that match workplace requirements and foster employability. She adds that 'the employers' perceptions play a key role in the definition of the required skills for graduates. Thus, universities and higher education at large will have to go a long and uneasy way to meet the employability standards.

Table 1

Skills Frameworks: Scope and Appliance

\begin{tabular}{|c|c|c|}
\hline $\begin{array}{l}\text { Skills Frameworks \& } \\
\text { Concepts }\end{array}$ & $\begin{array}{l}\text { Period or Year of Concept } \\
\text { Introduction } \\
\end{array}$ & Scope and Commentary \\
\hline 21st Century Skills & 1981 (US) & $\begin{array}{l}\text { Launched by the US Department of Education, spread to Canada, the UK, } \\
\text { New Zealand, then to other OECD countries } \\
\text { The report 'A Nation at Risk: The Imperative for Educational Reform' (1983) } \\
\text { stated } \\
\text { - A Need for a Learning Society; } \\
\text { - Five New Basics (English, maths, science, computer science, } \\
\text { social studies); } \\
\text { - Other Important Subjects; } \\
\text { - Skills and Abilities (mainly learning skills, digital skills, and } \\
\text { career \& life skills) }\end{array}$ \\
\hline Life Skills & 1999 (WHO), 2012 (UNICEF) & $\begin{array}{l}\text { abilities to meet life demands and challenges, also known as psychosocial } \\
\text { competency }\end{array}$ \\
\hline Skills for a Digital World & 2016 (OECD) & $\begin{array}{l}\text { ICT generic skills, ICT specialist skills, ICT complementary skills, and } \\
\text { foundation skills§ }\end{array}$ \\
\hline $\begin{array}{l}\text { European } \\
\text { Portfolio }\end{array}$ & $1989-2011(\mathrm{EU})$ & $\begin{array}{l}\text { developed by the Language Policy Programme of the Council of Europe and } \\
\text { linked to the Common European Framework of Reference for Languages. } \\
\text { The documents provide information on language curricula, assessment } \\
\text { instruments, the skills acquired by L2 learners and the levels of the } \\
\text { language proficiency in the EU languages }\end{array}$ \\
\hline Europass of Skills & $2004(\mathrm{EU})$ & soft skills for digital and innovative activities \\
\hline $\begin{array}{l}\text { Key Competences for } \\
\text { Lifelong Learning }\end{array}$ & $2006(\mathrm{EU})$ & $\begin{array}{l}\text { Adopted as an annex to a Recommendation of the European Parliament } \\
\text { and the Council }\end{array}$ \\
\hline $\begin{array}{l}\text { Education for Sustainable } \\
\text { Development Skills }\end{array}$ & 2015 (UN) & $\begin{array}{l}\text { skills to solve environmentally important problems and lead an } \\
\text { environmentally aware way of life }\end{array}$ \\
\hline Soft Skills & early 2000s & $\begin{array}{l}\text { a combination of skills and personal attributes necessary for efficient } \\
\text { performance in most job }\end{array}$ \\
\hline Employability Skills & early 2000s & $\begin{array}{l}\text { personal and professional skills, experiences and attributes enabling people } \\
\text { to get a job. Sets may vary depending on the economy segment }\end{array}$ \\
\hline
\end{tabular}

The studies of skills, skills frameworks, and employability are on the rise in education and other social sciences as the themes address the challenges emerging in the society and economy at large. The more research, the better understanding of the intrinsic processes we will possess. JLE sees the above topics as relevant and essential in respect to the JLE scope and mission. 


\section{Conflict of Interest}

The authors declare that they have no conflict of interest.

\section{References}

Dittes, S., Richter, S., Richter, A. \& Smolik, S. (2019). Toward the workplace of the future: How organizations can facilitate digital work. Business Horizons, 62, 649-661. doi: https://doi.org/10.1016/j.bushor.2019.05.004

Fugate, M., Kinicki, A. J., \& Ashforth, B. E. (2004). Employability: A psycho-social construct, its dimensions, and applications. Journal of Vocational Behaviour, 65, 14-38. doi: https://doi.org/10.1016/j.jvb.2003.10.005

Nikitina, L., \& Furuoka, F. (2012). Sharp focus on soft skills: A case study of Malaysian university students' educational expectations. Education Research for Policy and Practice, 11, 207-224. doi: https://doi.org/10.1007/ s10671-011-9119-4

Raitskaya, L. \& Tikhonova, E. (2018). Perceptions of soft skills by Russia's university lecturers and students in the context of the world experience. RUDN Journal of Psychology and Pedagogics, 15(3), 350-363. doi: https://doi. org/10.22363/2313-1683-2018-15-3-350-363

Suleman, L. (2016). Employability skills of higher education graduates: Little consensus on a much-discussed subject. Procedia: Social and Behavioral Sciences, 228, 169-174. doi: https://doi.org/10.1016/j.sbspro.2016.07.025

OECD (2015). Skills for social progress: The power of social and emotional skills. OECD skills studies. Paris, France: OECD Publishing. doi: https://doi.org/10.1787/9789264226159-en

van Laar, E., van Deursena, A. J. A. M., van Dijka, J. A. G. M., \& de Haanb, J. (2019). Determinants of 21st-century digital skills: A large-scale survey among working professionals. Computers in Work Behavior, 100, 93-104. doi: https://doi.org/10.1016/j.chb.2019.06.017

Wals, A. E. J. (2012). Learning our way out of un-sustainability: The role of environmental education. In S. Clayton (Ed.), Oxford handbook on environmental and conservation psychology. London, UK: Oxford University Press.

Wals, A. E. J., Benavot, A. (2017). Can we meet the sustainability challenges? The role of education and lifelong learning. European Journal of Education, 52, 404-413. doi: https://doi.org/10.1111/ejed.12250

Wick, A., Withycombe, L., \& Redman, C. L. (2011). Key competencies in sustainability: A reference framework for academic program development. Sustainability Science, 6, 203-218. doi: https://doi.org/10.1007/s11625-011$0132-6$ 